\title{
System Dynamics for Sustainable Transportation Policies: A Systematic Literature Review
}

\author{
Dinâmica de Sistemas aplicada a políticas de transporte \\ sustentável: uma revisão sistemática
}

Wlisses Bonelá Fontoura [a] [D, Glaydston Mattos Ribeiro [a] [D]

[a] Universidade Federal do Rio de Janeiro, Rio de Janeiro, RJ, Brazil

How to cite: Fontoura, W. B., \& Ribeiro, G. M. (2021). System Dynamics for Sustainable Transportation Policies: A Systematic Literature Review. urbe. Revista Brasileira de Gestão Urbana, v. 13, e20200259.

https://doi.org/10.1590/2175-3369.013.e20200259

\section{Abstract}

Systems Dynamics (SD) is an efficient method that allows to analyze systems with dynamic complexity and policy resistance. The holistic approach of SD is suitable to analyze the current transportation problems. Among the applications of SD in the transportation sector, the use of this tool in the development and implementation of sustainable transport policies stands out. In this context, this paper aims to conduct a systematic literature review to assess the use of SD in the development and implementation of urban policies focused on sustainable transportation. The results show that most studies analyze policies focused on reducing the negative externalities of transportation, highlighting the efforts to reduce air pollutant emissions and traffic congestion. However, we did not find a study that analyzes non-motorized and motorized modes by economic, environmental, social, spatial and traffic variables. At the end of this study, the gaps found in the literature are pointed out, being available to further exploration in future studies.

Keywords: Sustainable transportation. Urban mobility. Urban policies. System dynamics. Systematic literature review.

\section{Resumo}

A Dinâmica de Sistemas (DS) é um método eficiente que permite analisar os sistemas com complexidade dinâmica e resistência política. A abordagem holística da DS é adequada para os atuais problemas de transporte. Entre as diversas aplicações da SD no setor de transporte, destaca-se o uso dessa ferramenta no desenvolvimento e implementação de políticas de transporte sustentável. Nesse contexto, este artigo tem o objetivo realizar uma revisão sistemática para avaliar o uso da DS no desenvolvimento e na implementação de políticas urbanas focadas no transporte sustentável. Os resultados mostram que grande parte dos estudos analisa políticas focadas na redução das externalidades negativas do transporte, destacando os

WBF is industrial engineer, Master of Science in Transportation Engineering, e-mail: wlisses@pet.coppe.ufrj.br GMR is civil engineer, PhD in Applied Computation, e-mail: glaydston@pet.coppe.ufrj.br 
esforços para reduzir a emissão de poluentes e o congestionamento. Entretanto, não encontramos na literatura um estudo que analise os modos não motorizados e motorizados por meio das variáveis econômicas, ambientais, sociais, de uso do solo e de tráfego. Ao final deste estudo, são apontadas as lacunas encontradas na literatura que podem ser exploradas em estudos futuros.

Palavras-chave: Transporte sustentável. Mobilidade urbana. Políticas urbanas. Dinâmica de Sistemas. Revisão sistemática.

\section{Introduction}

Intensive urban growth can lead to environmental, economic, social and traffic issues (Khakee, 2014; Hassan and Lee, 2015). Among the sectors impacted by the rapid unstructured urbanization, transportation is one of the highlights (Lin and $\mathrm{Du}$, 2015). The new travel pattern exacerbates the negative externalities in urban areas, resulting in frequent traffic congestion, air pollution, increase in the number of accidents, health problems, noise, among other problems (Bubel and Szymczyk, 2016; Valdes et al., 2016).

In this context, it is noted that the rapid urbanization and motorization are threats to sustainable development (Pérez \& Carillo, 2014). Therefore, measures must be taken to ensure urbanization in a sustainable way. For this, urban planners must identify the causes of the negative externalities in order to develop sustainable transportation policies (Li et al., 2012). These policies must incorporate economic viability, environmental stability and social equity through the management of travel demand and efficient land use (Machado and Piccini, 2018; Litman, 2019).

Due to its complexity, the transportation systems should not be analyzed by linear approaches (Wang et al., 2008). Thus, System Dynamics (SD) is an alternative for analyzing these problems, as this approach helps to understand complex systems (Sterman, 2001). Used for design policies, SD is an efficient method to achieve a good interpretation of the systems in situations of dynamic complexity and policy resistance (Sterman, 2000).

SD is an interdisciplinary approach that has been widely applied to several management issues (Leopold, 2016). In the transportation sector, the applicability of this method has been evaluated by several authors. In one of the first studies about the subject, Abbas and Bell (1994) compared SD with the traditional transport modelling and simulation approaches, pointing out that SD is a useful tool to support policy analysis and decision-making in transport systems.

Regarding the urban transportation systems, the holistic approach of SD is suitable to analyze the current problems (Shepherd, 2014). Therefore, this tool is useful for urban transportation planning, helping city managers to design and to implement urban policies focused on sustainable transportation (Khanna et al., 1985; Batur and Koç, 2017).

Based on this discussion, the following research problem is identified: how to seek and identify information about the use of SD in the development and implementation of urban policies focused on sustainable transportation? Thus, the objective of this paper is to carry out a Systematic Literature Review (SLR) to verify the current situation of scientific research on the application of SD in the analysis of sustainable transportation policies.

In addition to this introductory section, this paper is organized as it follows: section 2 presents the methodology used in this study; section 3 shows the results of SLR and a critical analysis. Finally, the authors' main conclusions and recommendations for future research are presented in Section 4.

\section{Scientific Contributions}

Previous research has demonstrated the efficiency of SD in analyzing the implementation of urban policies. The present work was developed to identify the variety of sustainable transportation policies 
analyzed by the SD, as well as the motivation for carrying out those studies. This research presents bibliometric indicators about the papers published on the theme. The results demonstrate the behavior and trends in the literature. Therefore, this study aims to present the gaps in the literature, contributing to the development of new studies and, consequently, increasing the variety of models on the subject.

\section{Methodology}

A Systematic Literature Review (SLR) is essential to verify the state of a particular research field (Manivannan and Sanjeevi, 2012). The SLR not only allows to integrate quantitative data between studies, but it also summarizes the findings of a given field (Michie and Williams, 2003). Therefore, this method is not just a review of existing writings because it assesses existing contributions and identifies gaps in the literature that can be explored in future studies (Thomé et al., 2016).

There are several approaches in the literature to perform the SLR. Kitchenham et al. (2009) and Thomé et al. (2016) perform the SLR through eight-step procedures. In a similar way, Connolly et al. (2012) applied a procedure composed of ten steps. Regardless of the number of steps, the SLR is composed of three phases: planning the review; conducting a review; and the report and dissemination of results (Tranfield et al., 2003).

The reasons for doing the SLR are identified in the planning phase. In addition, the objective and the steps of the research are defined at this stage (Oliveira et al., 2017). According to Brereton et al. (2007), the papers related to the theme are identified and evaluated in the second phase (conducting review). In addition, data collection and synthesis are carried out at this stage. Finally, the report, presenting the results obtained in the research, is developed in the third phase (Thomé et al., 2016).

In order to achieve the objective of this paper, we adopted the procedure for systematic literature review proposed by Brereton et al. (2007), as illustrated in Fig. 1. The results obtained in the SLR are presented in the next section.

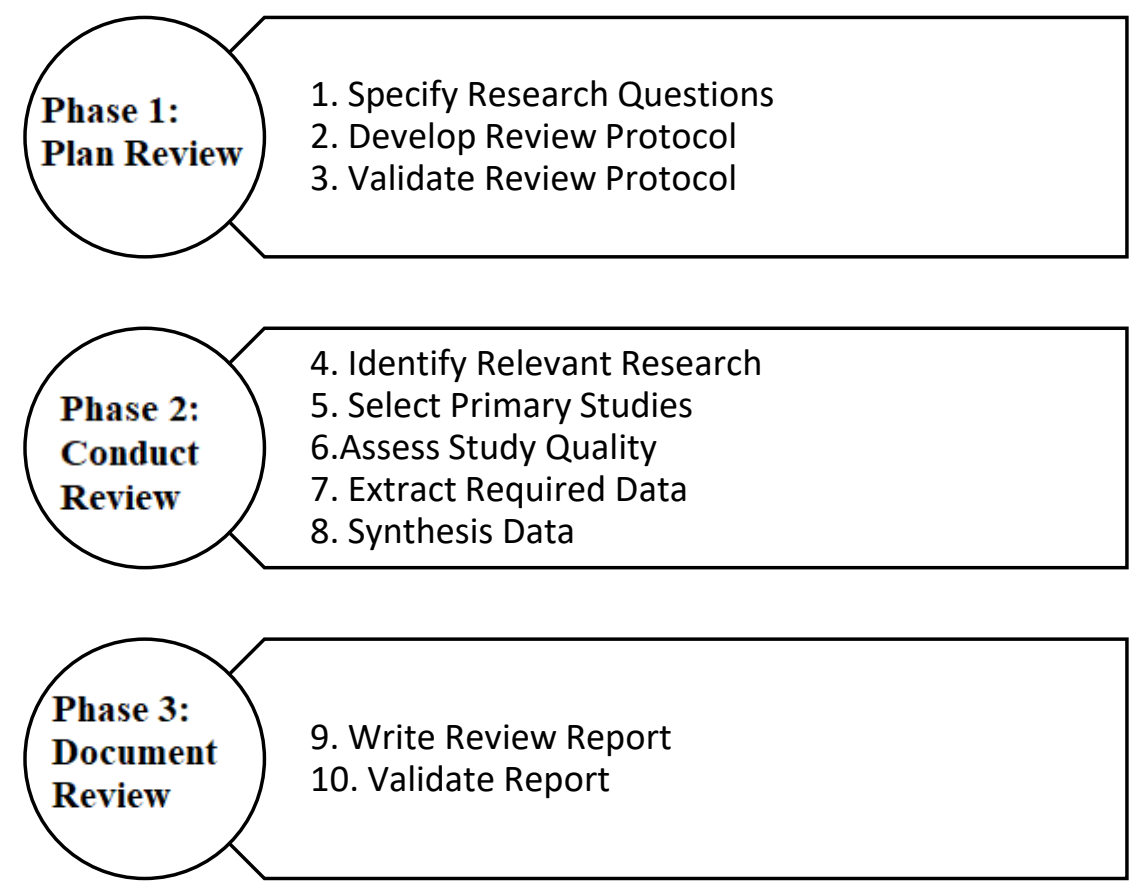

Figure 1 - Systematic literature process. Source: Brereton et al. (2007). 


\section{Systematic Literature Review}

In addition to determining the research objective, we established in Phase 1 the set of terms to be used in the search for papers. For this, we conducted an analysis of the keywords of five papers on the topic. Thus, to identify studies that assessed, through SD, the impact of urban policies focused in sustainable transportation, we chose the following combination of keywords: (urban policy AND sustainable transportation AND system dynamics) OR (urban policy AND urban mobility AND system dynamics). The logical operators "or" and "and" were applied to facilitate the combination of keywords and the selection of papers. Finally, the search engines used the words in the title, abstract and keywords to find papers.

In the review plan, the delimitation of the search was also determined. We opted to restrict the search to papers published in international journals indexed and peer-reviewed in order to ensure the quality of the studies, as recommended by Shepherd (2014). Seeking to identify the maximum number of SD applications in the analysis of sustainable transportation policies, we did not set any restrictions about the year of publication. In addition, due to the importance of sustainable transportation for the development of any country, we did not adopt a specific geographical delimitation.

Bramer et al. (2017) recommend to use multiple databases in order to obtain relevant references and, consequently, good results in an SLR. In this study, we searched for papers in five bases: Web of Science, Compendex, Scopus, Directory of Open Access Journals (DOAJ) and EBSCO. As a result, 347 papers were identified.

After searching for papers in each database, we:

I. Eliminate duplicated papers;

II. Read the title and the abstract of each paper to select those aligned with the research theme; and

III. Include the selected papers in the bibliographic portfolio.

In order to select the papers, first, we checked if the study analyzed an urban policy using SD. Then, we analyzed the policy presented in the study. Thus, we selected the studies that presented the analysis of an existing urban policy focused on sustainable transportation or an analysis of alternative policies or measures to be implemented in urban transportation systems. These policies took into account, in some way, at least one of the following aspects: social, environmental, economic, traffic and land use factors.

To include papers in the bibliographic portfolio, from the second database on, it was verified if the selected papers had not already been included in the bibliographic portfolio as a result of the search in a previous database. If so, the paper was not included. Therefore, 23 studies were included for the development of the SLR, as can be seen in Table 1.

Table 1 - Identification, selection and inclusion of papers

\begin{tabular}{lllll}
\hline Database & Identified & Duplicates & Selected & Included \\
\hline Web of Science & 100 & 1 & 15 & 15 \\
Compendex & 99 & 1 & 15 & 6 \\
Scopus & 144 & 0 & 18 & 2 \\
DOAJ & 1 & 0 & 0 & 0 \\
EBSCO & 3 & 0 & 3 & 0 \\
Total & 347 & 2 & 51 & 23 \\
\hline
\end{tabular}

Source: Authors (2020).

Besides the search and selection of papers, Phase 2 performers a synthesis data. This synthesis and the analysis of the research results (Phase 3 ) are presented below. 


\section{Synthesis data}

To perform the synthesis data, we use Microsoft Excel in this study. We also used VOSviewer for constructing and viewing bibliometric maps. This bibliometric software allows users to visualize patterns and trends in the literature by building maps based on data in the papers (Eck et al., 2010).

Among the included papers in the bibliographic portfolio, the first paper that used SD as a tool for analyzing sustainable transportation policies was published in 2008. As can be seen in Fig. 2, the number of publications on this topic began to grow in 2014. It is worth mentioning that the search for papers was carried out in the last week of January 2020, so our base line is 2019. Thus, it is observed that in the first month of 2020 alone, it was published almost the same number of studies published in 2019. This information shows that SD is being used increasingly to evaluate and define sustainable transportation policies.

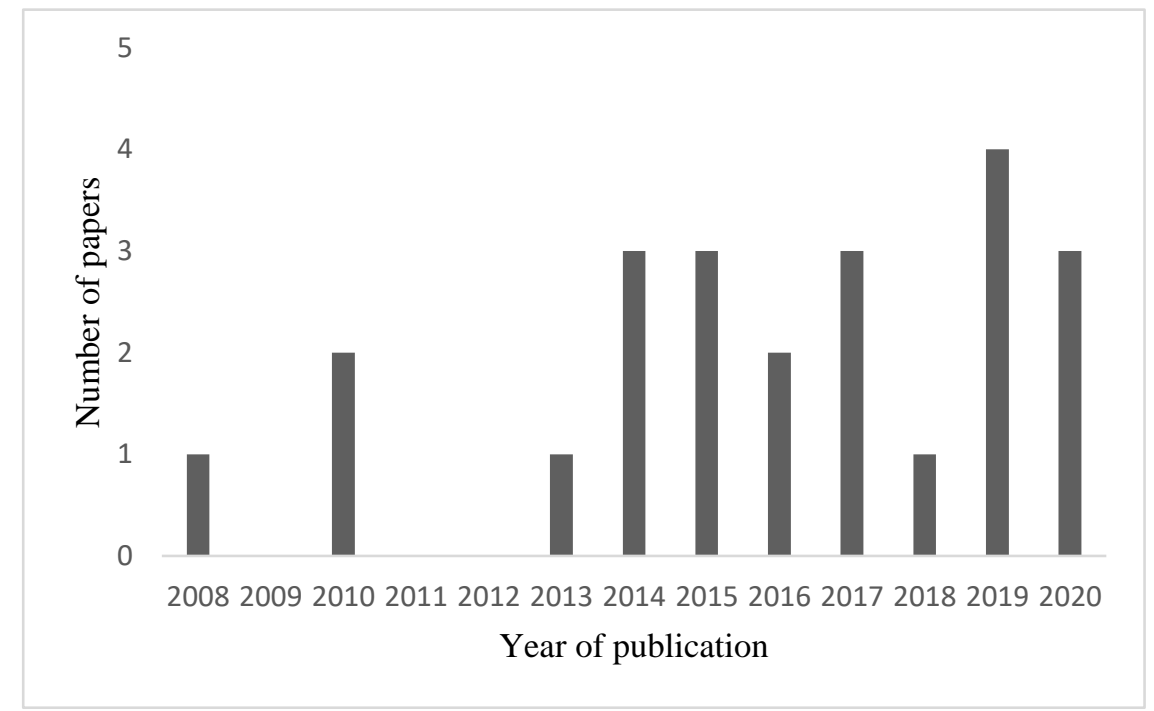

Figure 2 - Distribution of papers based on the year of publication. Source: Authors (2020).

The study developed by Wang et al. (2008) is one of the most relevant papers in the bibliographic portfolio, with 173 citations. This value may be associated with the fact that it was the first published paper. The study developed by Haghshenas et al. (2015) is also one of the prominent papers. Even though it was published in 2015, the paper has 90 citations, i.e., an average of 22.50 citations per year. After analyzing the total number of citations and the average number of citations per year, we selected the five most outstanding papers, which are shown in Table 2.

Table 2 - Included papers with the highest number of citations

\begin{tabular}{|c|c|c|c|c|}
\hline Authors & Title & Year & $\begin{array}{l}\text { Total number } \\
\text { of citations }\end{array}$ & $\begin{array}{l}\text { Number of } \\
\text { citations per } \\
\text { year }\end{array}$ \\
\hline Wang et al. & $\begin{array}{l}\text { System Dynamics Model of Urban Transportation } \\
\text { System and Its Application }\end{array}$ & 2008 & 173 & 15.73 \\
\hline Armah et al. & $\begin{array}{l}\text { A systems dynamics approach to explore traffic } \\
\text { congestion and air pollution link in the city of Accra, } \\
\text { Ghana }\end{array}$ & 2010 & 100 & 11.11 \\
\hline $\begin{array}{l}\text { Haghshenas } \\
\text { et al. }\end{array}$ & $\begin{array}{l}\text { Evaluation of sustainable policy in urban } \\
\text { transportation using system dynamics and world } \\
\text { cities data: A case study in Isfahan }\end{array}$ & 2015 & 90 & 22.50 \\
\hline Cheng et al. & $\begin{array}{l}\text { Urban transportation energy and carbon dioxide } \\
\text { emission reduction strategies }\end{array}$ & 2015 & 66 & 16.50 \\
\hline Ercan et al. & $\begin{array}{l}\text { Investigating carbon footprint reduction potential of } \\
\text { public transportation in United States: A system } \\
\text { dynamics approach }\end{array}$ & 2016 & 53 & 17.67 \\
\hline
\end{tabular}

Source: Authors (2020). 
The papers included in the bibliographic portfolio are distributed in 19 scientific journals. Among them, Sustainability stands out with the highest concentration of papers (three publications). As can be seen in Table 3, the Journal of Cleaner Production and the Journal of Simulation also stand out with two papers each. The other journals have only one publication about the subject. In the references of the included papers, it is observed that the cited papers are from 596 journals. In this list, Transport Policy and Energy Policy stand out with more than 30 cited papers.

Table 3 - Journals with the highest number of publications

\begin{tabular}{lll}
\hline Journal & \# Papers & JCR \\
\hline Sustainability & 3 & 4.624 \\
Journal of Cleaner Production & 2 & 6.395 \\
Journal of Simulation & 2 & 1.533 \\
\hline
\end{tabular}

Source: Authors (2020).

The papers included in the bibliographic portfolio have 64 authors. Regarding the nationality of these authors, China is the country with the largest number of publications, followed by Brazil and the United States, as shown in Fig. 3.

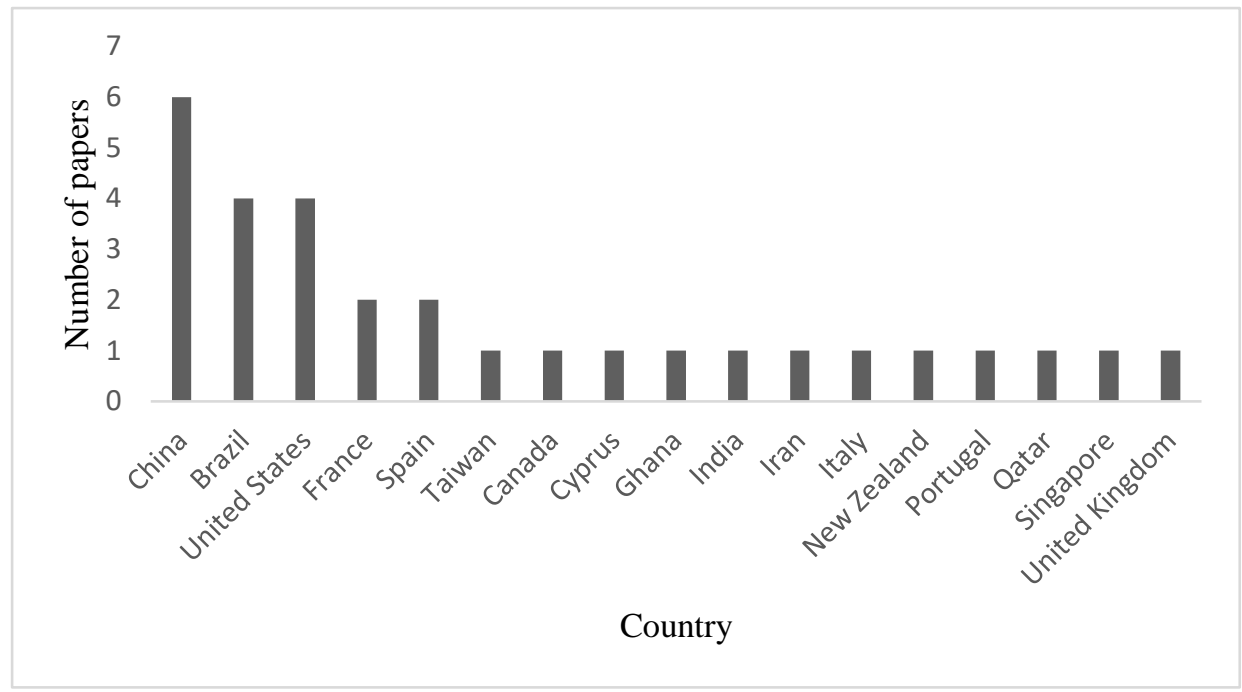

Figure 3 - Geographical distribution of included papers. Source: Authors (2020).

Finally, we analyzed the keywords used in the included papers. There were identified 70 keywords in the bibliographic portfolio. Fig. 4 presents the keywords network in which each node represents a keyword. The size of each node reflects the number of keyword occurrences in the portfolio. In addition, Fig. 4 presents how the keywords are connected, i.e., it lists the keywords that are used together. As can be seen, the most used keywords are system dynamics, sustainable transportation and $\mathrm{CO}_{2}$ emissions. 


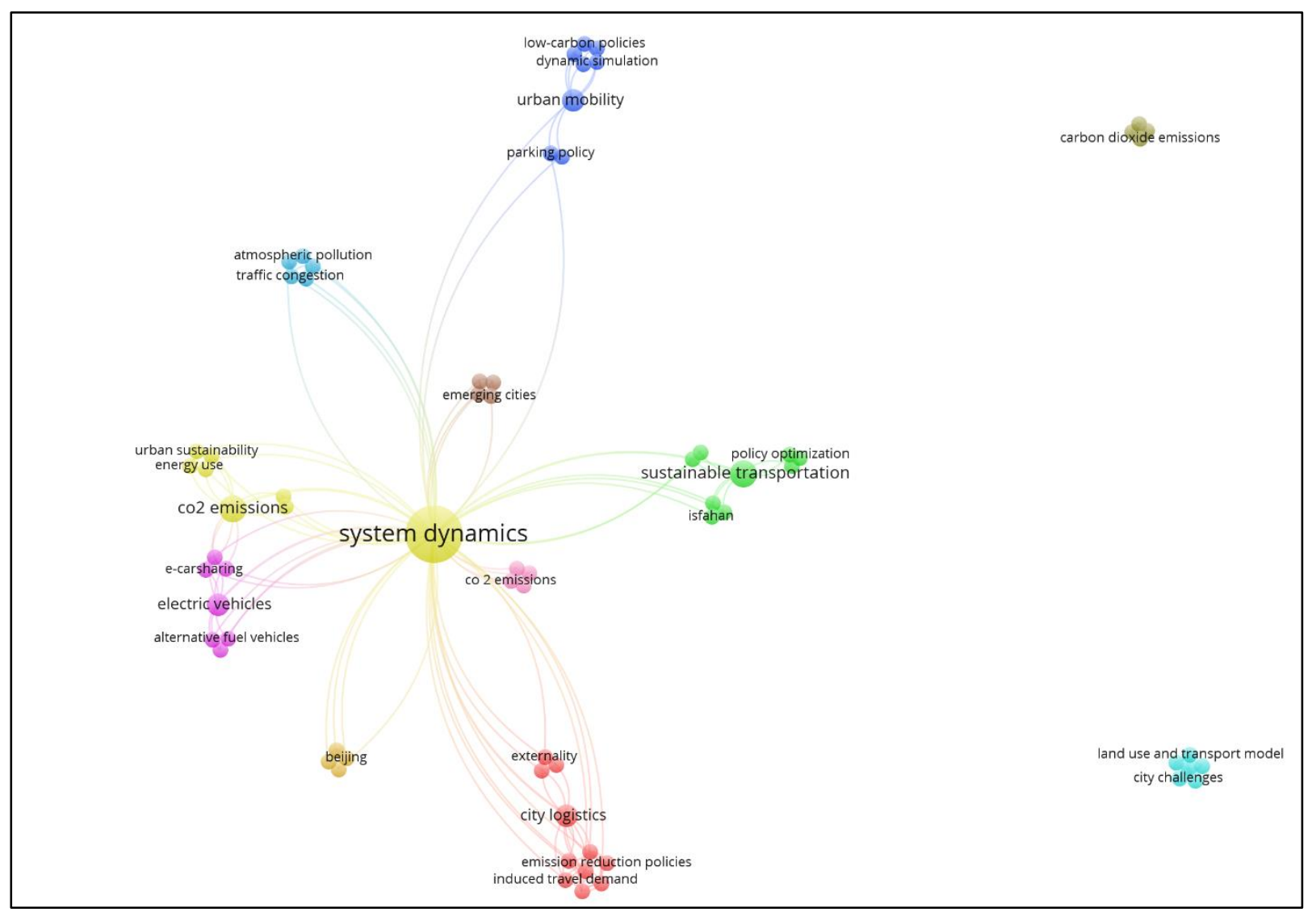

Figure 4 - Keywords network. Source: Authors (2020).

It is worth mentioning that VOSviewer groups the keywords according to the way they are typed. Therefore, if a term is typed in different ways, it will be shown more than once in the keywords network. For example, " $\mathrm{CO}_{2}$ " and "carbon dioxide emissions" are the same term, but they are shown separately in the Figure 4. However, we counted them as one keyword.

Another interesting factor in the keywords network is that the terms "land use and transport model" and "city challenges" are isolated. This is because these terms were presented as keywords only in one study focused in land use. Since they are not used together with other keywords, they have no connections in the keywords network.

Table 4 presents the synthesis of SLR with all the sustainable transportation policies that were analyzed through the SD and the main results. In addition, Table 3 also present the modes of transport (non-motorized and motorized), the sub-models (Economy, Environmental, Land Use, Social and Traffic Congestion) and the simulation time of each model. Thus, the analysis of the SLR results is presented in the next section.

Table 4 - Synthesis of SLR

\begin{tabular}{|c|c|c|c|c|c|}
\hline Authors & Policies & $\begin{array}{l}\text { Mode of } \\
\text { Transport* }\end{array}$ & Sub-models** & $\begin{array}{l}\text { Simulation } \\
\text { Time }\end{array}$ & Main Results \\
\hline $\begin{array}{l}\text { Wang et al. } \\
\text { (2008) }\end{array}$ & Vehicle development & $M$ & $\begin{array}{l}\text { ECO, ENV, and } \\
\text { TC }\end{array}$ & 50 years & $\begin{array}{l}\text { The authors suggest restrain the use } \\
\text { and the ownership of private vehicles. }\end{array}$ \\
\hline $\begin{array}{l}\text { Armah et } \\
\text { al. (2010) }\end{array}$ & $\begin{array}{l}\text { Government policy } \\
\text { and planning; Travel } \\
\text { demand } \\
\text { management; and } \\
\text { Supply management }\end{array}$ & M & $\begin{array}{l}\text { ECO, ENV, } \\
\text { SOC, and TC }\end{array}$ & $\begin{array}{l}\text { Not } \\
\text { performed }\end{array}$ & $\begin{array}{l}\text { Proposed measures: development of a } \\
\text { public transport system, road network } \\
\text { expanding and enhancing, and travel } \\
\text { demand management alternatives. }\end{array}$ \\
\hline
\end{tabular}

(to be continued) 
Table 4 - Synthesis of SLR

\begin{tabular}{|c|c|c|c|c|c|}
\hline Authors & Policies & $\begin{array}{l}\text { Mode of } \\
\text { Transport* }\end{array}$ & Sub-models** & $\begin{array}{l}\text { Simulation } \\
\text { Time }\end{array}$ & Main Results \\
\hline $\begin{array}{l}\text { Liv et al. } \\
\text { (2010) }\end{array}$ & $\begin{array}{l}\text { Clean transportation; } \\
\text { Bus priority; Subway } \\
\text { priority; and Car trip } \\
\text { restriction }\end{array}$ & NM and $M$ & $\begin{array}{l}\text { ECO, ENV, and } \\
\text { LU }\end{array}$ & 15 years & $\begin{array}{l}\text { Pollutants, energy consumption and } \\
\text { land demand for roads will exceed the } \\
\text { capacity of Beijing in } 2020 \text {, if nothing } \\
\text { changes. The four policies have } \\
\text { positive results, but the integration of } \\
\text { the four measures shows better results. }\end{array}$ \\
\hline $\begin{array}{l}\text { Bernardino } \\
\text { and Van } \\
\text { der Hoofd } \\
\text { (2013) }\end{array}$ & Parking policy & M & $\begin{array}{l}\text { ECO, LU, and } \\
\text { TC }\end{array}$ & $\begin{array}{l}\text { Unavailable } \\
\text { data }\end{array}$ & $\begin{array}{l}\text { The parking policy regulates the } \\
\text { scarcity of parking and the traffic } \\
\text { congestion. Thus, the system performs } \\
\text { better, increasing the average speed } \\
\text { in the network by up to } 35 \% \text {. }\end{array}$ \\
\hline $\begin{array}{l}\text { Bisen et al. } \\
(2014)\end{array}$ & $\begin{array}{l}\text { Provision of pedestrian } \\
\text { lane; User defined } \\
\text { vehicle occupancy; } \\
\text { Impact of } \\
\text { telecommunication } \\
\text { application; and } \\
\text { Change in land use } \\
\text { characteristics }\end{array}$ & NM and $M$ & $\begin{array}{l}\text { ECO, ENV, LU, } \\
\text { and TC }\end{array}$ & 20 years & $\begin{array}{l}\text { Reduction of pollutant emissions and } \\
\text { traffic congestion and increase of the } \\
\text { average speed in the network. }\end{array}$ \\
\hline $\begin{array}{l}\text { Guzman et } \\
\text { al. }(2014)\end{array}$ & $\begin{array}{l}\text { Road charge pricing } \\
\text { policy }\end{array}$ & M & $\begin{array}{l}\text { ECO, ENV, LU, } \\
\text { and TC }\end{array}$ & 30 years & $\begin{array}{l}\text { Change in the modal split in radial } \\
\text { trips. Speed increases and, } \\
\text { consequently, the number of } \\
\text { accidents also increases. Car travel } \\
\text { has changed its destination pattern. } \\
\text { Fuel consumption and pollutant } \\
\text { emissions decreases. }\end{array}$ \\
\hline $\begin{array}{l}\text { Li et al. } \\
\text { (2014) }\end{array}$ & $\begin{array}{l}\text { Land use } \\
\text { management }\end{array}$ & M & $\begin{array}{l}\text { ECO, ENV, LU, } \\
\text { and SOC }\end{array}$ & 5 years & $\begin{array}{l}\text { The model has a good accuracy and } \\
\text { can be used as the macro-scale } \\
\text { model for estimating the aggregated } \\
\text { urban land use demand. }\end{array}$ \\
\hline $\begin{array}{l}\text { Cheng et } \\
\text { al. (2015) }\end{array}$ & $\begin{array}{l}\text { Fuel tax; Motorcycle } \\
\text { parking management; } \\
\text { and Free bus servisse }\end{array}$ & M & $\begin{array}{l}\text { ECO, ENV, } \\
\text { SOC, and TC }\end{array}$ & 30 years & $\begin{array}{l}\text { Fuel tax and motorcycle parking } \\
\text { management policies are more } \\
\text { efficient to restrict the growth of the } \\
\text { number of cars, the fuel consumption, } \\
\text { and } \mathrm{CO}_{2} \text { emissions. However, fuel tax } \\
\text { policy seems to be the most effective } \\
\text { cost. }\end{array}$ \\
\hline $\begin{array}{l}\text { Haghshenas } \\
\text { et al. (2015) }\end{array}$ & $\begin{array}{l}\text { Increase in private } \\
\text { infrastructure; Control } \\
\text { of urban sprawl; } \\
\text { Replacement of } \\
\text { vehicles; Car sharing } \\
\text { and carpooling; Travel } \\
\text { demand } \\
\text { management; } \\
\text { Providing more mixed } \\
\text { land use; and a set of } \\
\text { policies to improve } \\
\text { public and non- } \\
\text { motorized transport }\end{array}$ & NM and $M$ & $\begin{array}{l}\text { ECO, ENV, LU, } \\
\text { and SOC }\end{array}$ & 13 years & $\begin{array}{l}\text { Policy makers should prioritize the } \\
\text { development of policies related to } \\
\text { public and non-motorized transport } \\
\text { infrastructure. In addition, they must } \\
\text { prioritize the integration of modes with } \\
\text { effective prices and control the use of } \\
\text { cars. }\end{array}$ \\
\hline $\begin{array}{l}\text { Wen et al. } \\
(2015)\end{array}$ & Low-carbon policies & M & ECO and ENV & 13 years & $\begin{array}{l}\text { Increasing the utilization of Liquefied } \\
\text { Natural Gas vehicle (LNG) } \\
\text { considerably reduces pollutant } \\
\text { emissions. Vehicle quantity control } \\
\text { helps improve the sustainability of the } \\
\text { transportation system. }\end{array}$ \\
\hline
\end{tabular}

(to be continued) 
Table 4 - Synthesis of SLR

\begin{tabular}{|c|c|c|c|c|c|}
\hline Authors & Policies & $\begin{array}{l}\text { Mode of } \\
\text { Transport* }\end{array}$ & Sub-models** & $\begin{array}{l}\text { Simulation } \\
\text { Time }\end{array}$ & Main Results \\
\hline $\begin{array}{l}\text { Ercan et al. } \\
(2016)\end{array}$ & $\begin{array}{l}\text { Public transportation } \\
\text { policies; Alternative } \\
\text { fuel options (public } \\
\text { and private transport) }\end{array}$ & M & $\begin{array}{l}\text { ECO, ENV, and } \\
\text { TC }\end{array}$ & 60 years & $\begin{array}{l}\text { The public policies must be supported } \\
\text { by measures that are more aggressive. } \\
\text { The prioritization of public transport } \\
\text { and the improvements in the energy } \\
\text { consumption of cars has the potential } \\
\text { to reduce or even partially eliminate } \\
\text { the current growth in } \mathrm{CO}_{2} \text { emissions. }\end{array}$ \\
\hline $\begin{array}{l}\text { Macmillan } \\
\text { et al. (2016) }\end{array}$ & Pro-cycling policies & NM and $M$ & SOC & 20 years & $\begin{array}{l}\text { The model helps identify effective } \\
\text { policy levers to achieve sustained } \\
\text { growth in cycling. }\end{array}$ \\
\hline $\begin{array}{l}\text { Alonso et al. } \\
\text { (2017) }\end{array}$ & $\begin{array}{l}\text { Cordon toll } \\
\text { accompanied by } \\
\text { public transport } \\
\text { improvements; } \\
\text { Teleworking; and Re- } \\
\text { densification }\end{array}$ & M & $\begin{array}{l}\text { ECO, ENV, LU, } \\
\text { SOC, and TC }\end{array}$ & 19 years & $\begin{array}{l}\text { The three policies increase the } \\
\text { efficiency of the system. However, } \\
\text { teleworking is the most effective } \\
\text { measure. Analyzing only energy } \\
\text { consumption and pollution, re- } \\
\text { densification showed better results. }\end{array}$ \\
\hline $\begin{array}{l}\text { Menezes et } \\
\text { al. (2017) }\end{array}$ & Low-carbon policies & M & ENV & 30 years & $\begin{array}{l}\text { Policies that promote the use of } \\
\text { biofuels have the greatest potential to } \\
\text { reduce pollutant emissions. The } \\
\text { prioritization of public transport also } \\
\text { stands out in reducing emissions. }\end{array}$ \\
\hline $\begin{array}{l}\text { Procter et al. } \\
\text { (2017) }\end{array}$ & $\begin{array}{l}\text { Implementation of the } \\
\text { Light Rail Transit (LRT) }\end{array}$ & M & $\begin{array}{l}\text { ECO, ENV, LU, } \\
\text { and TC }\end{array}$ & 40 years & $\begin{array}{l}\text { The implementation of the LRT will } \\
\text { reduce emissions. Government targets } \\
\text { on energy consumption will not be met } \\
\text { without implementation. }\end{array}$ \\
\hline $\begin{array}{l}\text { Shen et al. } \\
\text { (2018) }\end{array}$ & $\begin{array}{l}\text { Strengthening urban } \\
\text { road construction; } \\
\text { Strengthening the } \\
\text { public transport } \\
\text { system; Limiting } \\
\text { private cars }\end{array}$ & M & ECO and TC & 10 years & $\begin{array}{l}\text { The three policies are effective, but } \\
\text { the authors emphasize the } \\
\text { importance of implementing them } \\
\text { simultaneously. }\end{array}$ \\
\hline $\begin{array}{l}\text { Batur et al. } \\
\text { (2019) }\end{array}$ & $\begin{array}{l}\text { Supply management } \\
\text { measures; Travel } \\
\text { demand } \\
\text { management (TDM) } \\
\text { policies }\end{array}$ & M & $\begin{array}{l}\text { ECO, ENV, and } \\
\text { LU }\end{array}$ & 10 years & $\begin{array}{l}\text { Travel demand management based } \\
\text { scenarios } \\
\text { outperform supply management } \\
\text { measures based scenarios. }\end{array}$ \\
\hline $\begin{array}{l}\text { Fontoura et al. } \\
\text { (2019a) }\end{array}$ & $\begin{array}{l}\text { Brazilian Urban } \\
\text { Mobility Policy (BUMP) }\end{array}$ & M & $\begin{array}{l}\text { ECO, ENV, and } \\
\text { TC }\end{array}$ & 30 years & $\begin{array}{l}\text { The BUMP implementation improves } \\
\text { the share of public transit and reduces } \\
\text { the pollutant emissions and traffic } \\
\text { congestion. Besides that, the results } \\
\text { show the importance of rideshare. }\end{array}$ \\
\hline $\begin{array}{l}\text { Fontoura et al. } \\
(2019 b)\end{array}$ & $\begin{array}{l}\text { Brazilian Urban } \\
\text { Mobility Policy (BUMP) }\end{array}$ & NM and $M$ & $\begin{array}{l}\text { ECO, ENV, and } \\
\text { TC }\end{array}$ & 32 years & $\begin{array}{l}\text { The BUMP implementation reduces } \\
\text { the negative externalities and, } \\
\text { consequently, increases the efficiency } \\
\text { of the urban transport system. }\end{array}$ \\
\hline $\begin{array}{l}\text { Papageorgiou } \\
\text { and } \\
\text { Demetriou } \\
\text { (2019) }\end{array}$ & $\begin{array}{l}\text { Public awareness of } \\
\text { the sustainable habits }\end{array}$ & NM & soc & 10 years & $\begin{array}{l}\text { Social learning and motivation to } \\
\text { change behaviors are effective in } \\
\text { promoting sustainable active mobility. } \\
\text { The introduction of Information and } \\
\text { Communication Technology } \\
\text { accelerates the shaping and diffusion } \\
\text { of a walking mindset. }\end{array}$ \\
\hline $\begin{array}{l}\text { Hu et al. } \\
(2020)\end{array}$ & $\begin{array}{l}\text { Urban passenger rail } \\
\text { transit network (URFT) } \\
\text { development }\end{array}$ & M & $\begin{array}{l}\text { EC, ENV, and } \\
\text { TC }\end{array}$ & 28 years & $\begin{array}{l}\text { URFT schemes with higher funding and } \\
\text { capacity reduces traffic congestion, } \\
\text { pollutant emissions and the number of } \\
\text { accidents. }\end{array}$ \\
\hline
\end{tabular}

(to be continued) 
Table 4 - Synthesis of SLR

\begin{tabular}{|c|c|c|c|c|c|}
\hline Authors & Policies & $\begin{array}{l}\text { Mode of } \\
\text { Transport* }\end{array}$ & Sub-models** & $\begin{array}{l}\text { Simulation } \\
\text { Time }\end{array}$ & Main Results \\
\hline $\begin{array}{l}\text { Keith et al. } \\
(2020)\end{array}$ & $\begin{array}{l}\text { Alternative fuel } \\
\text { vehicles; Hybrid- } \\
\text { electric vehicles; and } \\
\text { Battery electric } \\
\text { vehicles }\end{array}$ & $M$ & ENV & 30 years & $\begin{array}{l}\text { In order to obtain a low carbon } \\
\text { transportation sector, it is necessary to } \\
\text { integrate long-term policies, } \\
\text { considering the different vehicles } \\
\text { fuels, as well as vehicle platforms and } \\
\text { their interactions. }\end{array}$ \\
\hline $\begin{array}{l}\text { Luna et al. } \\
(2020)\end{array}$ & $\begin{array}{l}\text { E-carsharing growth } \\
\text { policy; and } \\
\text { Retirement policy for } \\
\text { conventional vehicles }\end{array}$ & M & ECO and ENV & 40 years & $\begin{array}{l}\text { E-carsharing reduces emissions and } \\
\text { increases awareness of electric } \\
\text { vehicles. The combination of the two } \\
\text { policies presents the best results for } \\
\text { reducing emissions and increasing } \\
\text { electric vehicle adoption. }\end{array}$ \\
\hline
\end{tabular}

${ }^{*} \mathrm{NM}=$ Non-motorized; $\mathrm{M}=$ motorized. ${ }^{*} \mathrm{ECO}=$ Economy; ENV = Environmental; $\mathrm{LU}=$ Land Use; SOC = Social; TC = Traffic Congestion. Source: Authors (2020).

\section{Analysis}

The problems of urban mobility become more evident in large urban centers and, therefore, the policy makers in these regions have been striving to meet urban sustainability standards (Pojani and Stead, 2015). Thus, the number of studies to solve such problems in those areas is increasing. All papers analyzed urban areas with more than two million inhabitants. However, it is worth mentioning that three studies did not assess the impact of policies in a city, but in a specific region. Fontoura et al. (2019a), Procter et al. (2017) and Keith et al. (2020) analyzed the Metropolitan Region of São Paulo (Brazil), the Research Triangle (North Carolina, USA) and the USA, respectively.

All papers assess the implementation of at least one policy. However, in almost all papers, the authors proposed the policies and measures analyzed in the studies. Considering the 23 papers, only five of them consider some policy or goal set by the government. Fontoura (2019a) and Fontoura (2019b) analyze the impact of the Brazilian Urban Mobility Policy implementation, being the only study that exclusively evaluates the impact of a public policy. Procter et al. (2017) proposed sustainable transportation policies and compared them with the goals set by the government. Finally, Liu et al. (2010) and Ercan et al. (2016) adjusted existing public policies, simulating ambitious scenarios.

Increasing the public transportation ridership and limiting private vehicles are the two most analyzed measures, present in $43 \%$ and $52 \%$ of the studies, respectively. When these measures are not adopted, studies generally assess policies related to alternative fuels (mainly for private vehicles). The incentive for non-motorized transport, is explored in few studies, being addressed in only $26 \%$ of the papers. Thus, it is observed that the major focus in these studies is to reduce the impact of private vehicles.

When it comes to sustainable transportation, two of the main concerns are the air pollutant emissions and the energy consumption. Therefore, these two factors are widely used to calculate sustainable transportation indicators (Cheng et al. 2015; Litman, 2019). In this context, approximately $87 \%$ of the models have the environment sub-model. In addition, of the 23 papers, nine studies aim to analyze policies focused on reducing emissions and/or energy consumption in transport systems. Among the measures analyzed, priority public transportation, alternative fuel options and fuel tax are highlighted.

After the Environmental sub-model, the Economy is the sub-model most present in the papers (78\%). This is justified since the economy directly affects travel demand and, consequently, the other 
sub-models (Fontoura et al., 2019b). Traffic Congestion is also one of the main negative externalities of the transportation system, becoming a big challenge for urban planners and policy-makers (Albalate and Fageda, 2019). Measures to solve this problem are presented in $65 \%$ of the studies from the bibliographic portfolio.

The Social and Land Use are the least analyzed sub-models in the studies, being represented in only $35 \%$ and $39 \%$ of the papers, respectively. Although the Social sub-model is not widely explored, two studies present a model that exclusively evaluate the social aspect of it. Macmillan et al. (2016) analyze how news about bicycle accidents affect the population and, consequently, the demand for this mode. After understanding the society, the culture and the human behavior, the authors propose procycling policies, and Papageorgiou and Demetriou (2019) analyze the effects of public awareness of the sustainable habits.

According to Zolfagharian et al. (2018), SD scholars are increasingly drawing to multi-method approaches to overcome the limitations of this approach. Therefore, they combine SD with one or more research methods to analyze complex problems and develop deeper solutions than a singlemethod study can do. Liu et al. (2010) developed an integrated optimization model for urban transportation-environmental system, using a system dynamic model and a linear optimization model.

In order to examine the urbanization process of Daqing City, Li et al. (2014) developed two models: an integrated system dynamic (SD) and CLUE-S model (SD-CLUES), and an integrated SD and stochastic cellular automata model (SD-CA). The first model clusters new urban developments in the downtown area or close to the main transportation networks. On the other hand, the second model allocates new urban cells in a scattered way across the study area. The authors compare the results of the two multi-level models and conclude that the SD-CA is closer to reality, presenting better results.

It is worth mentioning that some authors used existing models in the literature. Guzman et al. (2014) and Alonso et al. (2017) used the Metropolitan Activity Relocation Simulator (MARS), a strategic and dynamic Land-Use and Transport Interaction (LUTI) model created by Pfaffenbichler (2003).

The effects of implementing a new policy are not immediate, because there is a period of adaptation (Dupuis and Knoepfel, 2013). Policy-makers must take into account this period when formulating and analyzing new policies. So, regarding the simulation time, we noted that there is not a standard to analyze the impacts of sustainable transportation policies. Among the papers, the simulation time varied between 5 and 60 years, presenting an average of approximately 25 years.

Despite the analysis of several policies, we did not find in the literature a study that analyzed all modes of transport (motorized and non-motorized) and the five sub-models (Economy, Environment, Land Use, Social and Traffic Congestion) at the same time. Therefore, there is an opportunity for future research to develop a model that assesses the impact of sustainable transport policies considering all these factors.

\section{Final Considerations}

This paper aimed to verify the development of scientific research on System Dynamics (SD) applied to the analysis of sustainable transportation policies using a Systematic Literature Review (SLR) methodology. Thus, it was possible to investigate the occurrence and map the studies on this topic. In addition, the behavior of the scientific community on this subject was identified and analyzed.

From the SLR, it was possible to analyze the development of studies on the subject. We identified the outstanding papers, the most used keywords and the most analyzed policies. Besides, it was observed that China is the country with the largest number of publications about the subject, followed by Brazil and the United States. 
The SLR analysis shows that SD is a useful tool in analyzing the implementation of sustainable transport policies. This method allows to find the best measures and prioritize them. It is observed that most studies focus on reducing the negative externalities of transport, highlighting the search for reducing air pollutant emissions and traffic congestion. For this, the focus is still on private vehicles.

One of the results of this study was the identification of a gap in the literature. So, we suggested for future studies to develop a model that analyzes the effects of sustainable transportation policies, addressing at the same time non-motorized modes, motorized modes and the sub-models Economy, Environment, Land Use, Social and Traffic congestion.

Despite the use of multiple database to conduct this paper, there may be studies on the theme not present in these databases, so our analysis is open to improvements. In addition, there may be studies that were not found due to the terms used in the search for papers. For this reason, we also suggest performing the SLR using more databases and more keywords. This paper was relevant due to the increasing use of SD in the analysis of sustainable transport policies. Besides highlighting the gaps in the literature, this paper contributes to further research since the results assist researchers in finding information on the subject.

\section{References}

Abbas, K. A., \& Bell, M. G. H. (1994). System dynamics applicability to transportation modeling. Transportation Research Part A: Policy and Practice, 28(5), 373-390. http://dx.doi.org/10.1016/0965-8564(94)90022-1

Albalate, D., \& Fageda, X. (2019). Congestion, road safety, and the effectiveness of public policies in urban areas. Sustainability, 11(18), 1-21. http://dx.doi.org/10.7213/10.3390/su11185092

Alonso, A., Monzón. A., \& Wang, Y. (2017). Modeling land use and transport policies to measure their contribution to urban challenges: The case of Madrid. Sustainability, 9(378), 1-28, http://dx.doi.org/10.3390/su9030378

Armah, F., A., Yawson, D. O., \& Pappoe, A. N. M. (2010). A system dynamics approach to explore traffic congestion and air pollution in the city of Accra, Ghana. Sustainability, 2(1), 252-265. http://dx.doi.org/10.3390/su2010252

Batur, I., \& Koc, M. (2017). A review of System Dynamics applications in sustainable urban transportation. Proceedings of the European conference on sustainability, energy \& the environment, July 9-10, Brighton, United Kingdom.

Batur, I., Islam, S. B., \& Koc, M. (2019). Impact assessment of supply-side and demand-side policies on energy consumption and $\mathrm{CO}_{2}$ emissions from urban passenger transportation: The case of Istanbul. Journal of Cleaner Production, 219, 319-410. http://dx.doi.org/10.1016/j.jclepro.2019.02.064

Bisen, A., Verma, P., Chaube, A., \& Jain, R. (2014). Evaluating emission mitigation strategies for sustainable transportation system: a system dynamics approach. World Review of Intermodal Transportation Research, 5(2), 101124. http://dx.doi.org/10.1504/WRITR.2014.067228

Bernardino, J. P. R., \& Van der Hoofd, M. (2013). Parking policy and urban mobility level of service - System Dynamics as a modelling tool for decision making. European Journal of Transport and Infrastructure Research, 13(3), $239-258$. http://dx.doi.org/10.18757/ejtir.2013.13.3.3001

Bramer, W. M., Rethlefsen, M. L., Kleijnen, J., \& Franco, O. (2017). Optimal database combinations for literature searches in systematic reviews: a prospective exploratory study. Systematic Reviews, 6(245), 1-12.

http://dx.doi.org/10.1186/s13643-017-0644-y.

Brereton. P., Kitchenham, B. A., Budgen, D., Turner, M., \& Khalil, M. (2007). Lessons from applying the systematic literature review process within the software engineering domain. The Journal of Systems and Software 80(4):571-583. http://dx.doi.org/ 10.1016/j.jss.2006.07.009

Bubel, D., \& Szymczyk, K. (2016). The Smart Freight projects as a superior way to cope with congestion and environmental negative externalities in urban areas. Transportation Research Procedia, 16, 25-34. http://dx.doi.org/10.1016/j.trpro.2016.11.004

Cheng, Y., Chang, Y., \& Lu, I. J. (2015). Urban transportation energy and carbon dioxide emission reduction strategies. Applied Energy, 157, 953-973. http://dx.doi.org/10.1016/j.apenergy.2015.01.126 
Connolly, T. M., Boyle, E. A., MacArthur, E., Hainey, T., \& Boyle, J. M. (2012) A systematic literature review of empirical evidence on computer games and serious games. Computer \& Education, 59, 661-686.

http://dx.doi.org/10.1016/j.compedu.2012.03.004

Dupuis, J., \& Knoepfel, P. (2013). The adaptation policy paradox: The implementation deficit of policies framed as climate change adaptation. Ecology and Society, 18(4), 1-16. http://dx.doi.org/10.5751/ES-05965-180431

Eck, N. J., Waltman, L., Dekker, R., \& Berg, J. (2010). A comparison of Two Techniques for Bibliometric Mapping: Multidimensional Scaling and VOS. Journal of the American Society for Information Science and Technology, 61(12), 2405-2416. http://dx.doi.org/10.1002/asi.21421

Ercan T., Onat, N. C., \& Tatari, O. (2016). Investigating carbon footprint reduction potential of public transportation in United States: A system dynamic approach. Journal of Cleaner Production, 133(1), 1260-1276.

http://dx.doi.org/10.1016/j.jclepro.2016.06.051

Fontoura, W. B., Chaves, G. L. D., \& Ribeiro, G. M. (2019a). The Brazilian Urban Mobility Policy: The impact in São Paulo transport system using system dynamics. Transport Policy, 73, 51-61. http://dx.doi.org/10.1016/j.tranpol.2018.09.014

Fontoura, W. B., Ribeiro, G. M., Chaves, G. L. D. (2019b). A framework for evaluating dynamic impacts of the Brazilian Urban Mobility Policy for transportation socioeconomic systems: A case study in Rio de Janeiro. Journal of Simulation, http://dx.doi.org/10.1080/17477778.2019.1701392

Guzman, L. A., de la Hoz, D., \& Monzón, A. (2014). Optimal and long-term dynamic transport policy design: Seeking maximum social welfare through a pricing scheme. International Journal of Sustainable Transportation, 8(4), 297-316. http://dx.doi.org/10.1080/15568318.2012.696772

Haghshenas, H., Vaziri, M., \& Gholamialam, A. (2015). Evaluation of sustainable policy in urban transportation using system dynamics and world cities data: A case study in Isfahan. Cities, 45, 104-115.

http://dx.doi.org/10.1016/j.cities.2014.11.003

Hassan, A., M., \& Lee. H. (2015). Toward the sustainable development of urban areas: An overview of global trends in trials and policies. Land Use Policy, 48, 199-212. http://dx.doi.org/10.1016/j.landusepol.2015.04.029

Hu, W., Dong, J., Hwang, B., Ren, R., Chen, Y., \& Chen, Z. (2020). Using system dynamics to analyze the development of urban freight transportation system based on rail transit: A case study of Beijing. Sustainable Cities and Society, 53, 113. http://dx.doi.org/10.1016/j.scs.2019.101923

Keith, D. R., Struben, J. J. R., \& Naumov, S. (2020). The diffusion of alternative fuel vehicles: A generalized model and future research agenda. Journal of Simulation. http://dx.doi.org/10.1080/17477778.2019.1708219

Khakee, A. (2014). An unbalanced model for sustainable urban development. International Journal of Urban Sustainable Development, 6(1), 52-64. http://dx.doi.org/10.1080/19463138.2013.870765

Khanna, I. K., Singh, N., Vrat, P. (1985). System Dynamics in Urban Transportation Planning and Policy Analysis. Proceedings of the Conference of the System Dynamics Society, Keystone, C0, 453-462.

Kitchenham, B., Brereton, O. P., Budgen, D., Turner, M., Bailey, J., \& Linkman, S. (2009). Systematic literature reviews in software engineering - A systematic literature review. Information and Software Technology, 51(1), 7-15, http://dx.doi.org/10.1016/j.infsof.2008.09.009

Leopold, A. (2016). Energy related system dynamic models: a literature review. Central European Journal of Operations Research, 24, 231-261. http://dx.doi.org/10.1007/s10100-015-0417-4

Li, Y., Li, Y., Zhou, Y., Shi, Y., \& Zhu, X. (2012). Investigating of a coupling model of coordination between urbanization and the environment. Journal of Environmental Management, 98, 127-133.

http://dx.doi.org/10.1016/j.jenvman.2011.12.025

Li, W., Wu, C., \& Zang, S. (2014). Modeling urban land use conversion of Daqing City, China: a comparative analysis of "top-down" and "bottom-up" approaches. Stochastic Environmental Research and Risk Assessment, 28(4), 817-828. http://dx.doi.org/10.1007/s00477-012-0671-0

Lin, B., \& Du, Z. (2015). How China's urbanization impacts transport energy consumption in the face of income disparity. Renewable and Sustainable Energy Cities, 52, 1693-1701. http://dx.doi.org/10.1016/j.rser.2015.08.006

Litman, T. (2019). Well Measured: Developing indicators for sustainable and livable transport planning. Victoria Transport Policy, Victoria, BC, Canada. 
Liu, H., Liu, T., Liu, L., Guo, H. C., Yu, Y. J., \&Wang, Z. (2010). Integrated simulation and optimization approach for the urban transportation-environmental system in Beijing. Journal of Environmental Informatics, 15(2), 99-111. http://dx.doi.org/10.3808/jei.201000170

Luna, T. F., Uriona-Maldonado, M., Silva, M. E., \& Vaz, C. R. (2020). The influence of e-carsharing schemes on electric vehicle option and carbon emissions: An emerging economy study. Transportation Research Part D, 70, 1-14. http://dx.doi.org/10.1016/j.trd.2020.102226

Machado, L., \& Piccini, L. S. (2018). Os desafios para a efetividade da implementação dos planos de mobilidade urbana. urbe. Revista Brasileira de Gestão Urbana, 10(1), 72-94. http://dx.doi.org/10.1590/2175-3369.010.001.A006

Macmillan, A., Roberts, A., Woodcock, J., Aldred, R., \& Goodman, A. (2016). Trends in local newspaper reporting of London cyclist facilities 1992-2012: the role of the media in shaping the systems dynamics of cycling. Accident Analysis and Prevention, 86, 137-145. http://dx.doi.org/10.1016/j.aap.2015.10.016

Manivannan, G., \& Sanjeevi, K. (2012). The Indian Journal of Medical Research (2000-2005): A Bibliometric Analysis. Journal of Advances in Library and Information Science, 2, 100-103.

Menezes, E., Maia, A. G., \& de Carvalho, C. S. (2017). Effectiveness of low-carbon development strategies: Evaluation of policy scenarios for the urban transport sector in a Brazilian megacity. Technological Forecasting \& Social Change, 114, 226-241. http://dx.doi.org/10.1016/j.techfore.2016.08.016

Michie, S., \& Williams, S. (2003). Reducing work related psychological ill health and sickness absence: a systematic literature review. Occupational and Environmental Medicine, 60, 3-9. http://dx.doi.org/10.1136/oem.60.1.3

Oliveira, C. M., Bandeira, R. A. M., Goes, G. V., Gonçalves, D. N. S., \& D’agosto, M. A. (2017). Sustainable vehicles-based alternatives in last mile distribution of urban freight transport: a systematic literature review. Sustainability, 9(8), 115. http://dx.doi.org/10.3390/su9081324

Papageorgiou, G., \& Demetriou, G. (2019). Investigating learning and diffusion strategies for sustainable mobility. Smart and Sustainable Built Environment. http://dx.doi.org/10.1108/SASBE-02-2019-0020

Pérez, J. C., \& Carillo, M. H. (2014). Multi-criteria approaches for urban passenger transport systems: a literature review. Annals of Operations Research, 226(1), 69-87. http://dx.doi.org/10.1007/s10479-014-1681-8

Pfaffenbichler, P. (2003). The strategic dynamic and integrated urban land use transport model MARS (PhD Thesis). Technical University of Vienna, Wien, Austria.

Pojani, D., \& Stead, D. (2015). Sustainable urban transport in the developing world: Beyond megacities. Sustainability, 7(6), 7784-7805. http://dx.doi.org/10.3390/su7067784

Procter, A., Bassi, A., Kolling, J., Cox, L., Flanders, N., Tanners, N., \& Araujo, R. (2017). The effectiveness of Light Rail transit in achieving regional $\mathrm{CO}_{2}$ emissions targets is linked to building energy use: insights from system dynamics modeling. Clean Technologies and Environmental Policy, 19(5). 1459-1474. http://dx.doi.org/10.1007/s10098-0171343-z

Shen, L., Du, L., Yang, X., Du, X., Wang, J., \& Hao, J. (2018). Sustainable strategies for transportation development in emerging cities in China: A simulation approach. Sustainability, 10(844), 1-22. http://dx.doi.org/10.3390/su10030844

Shepherd, S. P. (2014). A review of system dynamics models applied in transportation. Transportmetrica B: Transport Dynamics, 2(2), 83-105. http://dx.doi.org/10.1080/21680566.2014.916236

Sterman, J. (2000). Business Dynamics: System Thinking and Modelling for a Complex World. New York, USA: McGrawHill.

Sterman, J. D. (2001). System Dynamics modeling tool for learning a complex world. California Management Review, 43(4), 8-25. http://dx.doi.org/10.2307/41166098

Thomé, A. M. T., Scarvada, L. P., \& Scarvada, A. J. (2016). Conducting systematic literature review in operations management. Production Planning \& Control, 27(5), 408-420. http://dx.doi.org/10.1080/09537287.2015.1129464

Tranfield, D., Denyer, D., \& Smart. P. (2003). Towards a methodology for developing evidence-informed management knowledge by means of systematic review. British Journal of Management, 14, 207-222.

http://dx.doi.org/10.1111/1467-8551.00375 
Valdes, C., Monzon, A., \& Benitez, F. G. (2016). Sustainable urban transportation strategies: Searching for synergies. KSCE Journal of Civil Engineering, 20(3), 1066-1075. http://dx.doi.org/10.1007/s12205-016-0685-0

Wen, L., Cao, Y., \& Weng, J. (2015). System dynamics method for scenario simulation analysis of urban traffic $\mathrm{CO}_{2}$ emissions in Baoding. Journal of Information and Computational Science, 12(9), 3431-3443. http://dx.doi.org/ 10.12733/jics20106019

Wang, J., Lu, H., \& Peng, H. (2008). System Dynamics Model of Urban Transportation System and Its Application. Journal of Transportation Systems Engineering and Information Technology, 8(3), 83-89. http://dx.doi.org/10.1016/S1570-6672(08)60027-6

Zolfagharian, M., Romme, A. G. L., \& Walrave, B. (2018) Why, when and how to combine system dynamics with other methods: Towards an evidence-based framework. Journal of Simulation, 12(2), 98-114.

http://dx.doi.org/10.1080/17477778.2017.1418639

Editor: Fábio Duarte

Received on 15 Jul. 2020

Approved on 10 Oct. 2020 